\title{
The Role of Intangibles in the Economic Recovery Post- COVID-19 Pandemic
}

\author{
Rhonda A. Best
}

\section{ABSTRACT}

The strategic use of intangibles can create unlimited jobs globally. Intangibles are lucrative non-physical assets that every business enjoys but very few utilise effectively. By 2007 , early value management studies had proven that businesses with exponential growth had achieved those record performances after shifting their organising models. Today, there is new evidence to support further growth while addressing the societal issue of unemployment. Unemployment in this instance goes beyond the definition used in economics and includes facilitating the ease of an employee's transition from education to job or from job to job. Creating new jobs is especially important for countries facing tremendous development challenges, exacerbated by the COVID-19 pandemic. According to the International Labour Organization, the world's job loss due to the pandemic in $\mathbf{2 0 2 0}$ was equivalent to $\mathbf{2 5 5}$ million full-time jobs. At the same time, corporations globally have been taking a deeper look at governance practices and are closely examining the impact that commercial strategies have on the environment and society. In addition, the future of work is taking shape as hybrid work from home options are being explored for some roles. While the political and ethical implications of addressing global unemployment cannot be oversimplified, in theory, there can be open accessibility to jobs globally. Today's availability of education, the relative ease of international trade of services and technological advancement make this possible. This paper shares qualitative research that proposes the role of intangibles in solving unemployment, so a research university might consider furthering this vital work in intangibles.

Keywords: exponential growth, future of work, intangibles, international trade, open access jobs.

\section{Introduction: CURRENT MANAGEMENT Practices UNDERVALUE INTANGIBLES}

Since the industrial revolution, many of our management practices have incrementally progressed in line with significant market changes and the study of labour economics. For instance, women joined the workforce between 1914 and 1918. They helped to fill the gap left by a generation of military men during World War I. By the 1930s, constraints eased, and married women also worked. In the 1960 s, access to learning had begun to spread. Studies into the economic benefits of an investment in education meant that more countries wanted to earn a return. By 2008 a Canadian university had launched a new course attracting 25 students to their campus and a further 2300 worldwide via the internet. At the height of the 2008-2009 financial crisis, freelance or gig-work became popular. Over time,

\footnotetext{
1 Industry 4.0 describes the fourth revolution that is occurring in manufacturing due to digitisation. The first industrial revolution involved mechanisation through water and steam power. The second revolution, the mass production and assembly lines using electricity. The third used computers and automation, and the fourth industrial revolution enhanced what started in the third with intelligent and autonomous systems propelled by data and machine learning.
}

Submitted : August 13, 2021

Published : September 05, 2021

ISSN: $2507-1076$

DOI: $10.24018 /$ ejbmr.2021.6.5.1057

Rhonda A. Best *

BSc MBA

Alexander Bain \& Associates Limited, UK.

(e-mail: rhonda.best $@$ alexanderbain.co.uk)

*Corresponding Author organisations have continued to add to Adam Smith's philosophy, breaking down large jobs into tiny components as a means of enhancing production.

Two other fundamental changes have been underway in Industry $4.0^{1}$ and the new economy of intangible capital. According to Ocean Tomo, a well-known source for intangibles trends, these assets now represent about $90 \%$ of market capitalisation in Standard \& Poor companies. The statistic is up from around $17 \%$ forty-six short years ago.

Today's environment is one where intangibles dominate capital valuations and the use of prospector strategies ${ }^{2}$ are more widespread. Both situations suggest that there is a case for a zero-based approach to labour division and legislation. Although today's economic framework is significantly different, some commonly accepted labour concepts persist. These long-held approaches supported an economy that had depended on the old manufacturing industry and time-based work. As a result, profitability barriers exist across all sectors,

2 A prospector strategy is an aggressive competitive strategy that emphasises product innovation and searching for new market opportunities. It is the opposite of a defender strategy that protects products and market share. 
and lucrative trade opportunities remain unpursued. For example:

- While all employees access jobs through an application and interview process, there is evidence that some jobs performed by external contributors, not subject to such a process, have been instrumental to revenue generation for employers. These include roles like influencer marketers and independent management consultants.

- Pay practices in many sectors continue to be timebased. However, the value generated by some employees will last much longer if algorithms and technology replace those jobs. Inequitable pay practices are well-known for eroding employee engagement and the cause for increased attrition.

- Intangibles are a known source of high earnings. However, these assets are not monitored, measured, and reported monthly in management reports like physical assets are, creating an actual valuation gap. An integrated reporting framework is being developed for public companies though some are yet to implement it. With no benchmark agreed at a corporate level, many private companies find it tough to leverage their intangibles in the same way as public companies.

In 1991 Ronald Coase won the Nobel Prize in Economics for his theory that larger companies do better because they collate assets under one roof and enjoy lower transaction costs. Since then, centralised workspaces are the norm. However, as hybrid working was introduced in 2020 to curb the spread of coronavirus, there is proof that many strategic, creative and administrative roles can take place from decentralised spaces effectively and at lower costs.

- While organisations consistently focus on their client or customer pipelines, less emphasis is paid to developing a robust talent pipeline, although human capital is the greatest asset. Succession plans are often emergent, not deliberate.

When the pandemic struck, the threat to human capital and business continuity became real. It disrupted a fragile labour distribution model. Thus, it presents an opportune time for reexamining the division of labour and its part in the economic infrastructure required for effective modern organisations.

\section{Sunk Cost Valuation Militates against INNOVATION}

Valuations in publicly traded companies are comparatively easier to compute when determining worth than valuations in private companies. The market reflects appetite. Private companies, both large and small, use performance ratios derived from financial statements to estimate valuations. One primary method involves multiplying profits after tax by a determined Price to Earnings (P/E) ratio. There is a considerable drawback to this approach. Statutory financial statements that provide these ratios do not consider the intangible value private businesses create from managing and formulating strategy that leads to long-term prospects. As a result, there is a real valuation gap. Currently, recorded value does not contemplate the intangible.

According to Etymologists, the word 'intangible' has origins in France in the 1600s. It meant 'incapable of being touched'. However, it was not until the $1800 \mathrm{~s}$ that understanding of the figurative sense began to grow, and the meaning expanded to include 'that cannot be grasped by the mind'. Today's Cambridge dictionary explains intangibles as impossible to touch, describe exactly, or give an exact value.

The intricacy of intangibles makes this asset class tricky for the commercial world to wield successfully. Capitalism is still primarily measured by financial capital. Other types are capital - human, social, natural and produced - are discounted [1].

The book 'Capitalism without Capital: The Rise of the Intangible Economy' provides essential insights into this evolution of capitalism in the $21^{\text {st }}$ century's global economy and compares the differences from prior centuries when only physical assets justify their worth. Authors Haskel and Westlake describe the concept of intangible capital as including a range of competencies: internal know-how, computerised information, a networked society, innovative property, social relations, ideas, knowledge, and economic competencies.

The authors explained that the development of nonphysical assets like bespoke technology or algorithms could eventually slow productivity growth. The investment in technology to challenge a market leader could be a threat to going concern. Haskel and Westlake explored that the cost of developing intangible capital was a sunk cost and largely irrecoverable. They opined that, unlike buildings, furniture and hardware, the trouble with intangibles is that there are no ready buyers or market. The bespoke nature of these assets could mean that developing them can be risky for some businesses. If sunk costs present a threat to business continuity, then pursuing intangible economy, then has a knock-on impact on employment costs.

Employers of rival companies that want to benefit from the exploration of intangible capital require flexible rewarding structures to compete in the new economy. That change to the reward system involves:

a) Monitoring the breakdown of value creation within the business

b) More workers re-cooping some of the commercial risks that existed in the cottage industry preindustrial revolution

Yet, there is an alternative view.

\section{Sunk Cost IS A Misnomer When IT COMES TO INTANGIBLES}

What if pursuing intangibles could be separated from the outcome so irrecoverable costs are limited?

Intangibles offer more than goodwill. Non-physical assets represent the very essence of business continuity derived from the workforce's activities.

For example, a feature of intangibles is its evidence in the potential yield of exploratory research. Ten years ago, Moderna Inc., a biotech company based in Cambridge, Massachusetts, was incorporated. The corporation supports the research of synthetic messenger RNA, an inventive 
variation to the natural substance that directs protein production in cells throughout the human body. Moderna explored the use of biotech treatment for debilitating diseases like cancer and HIV. Raising over US\$2 bn in funding (equity, advances, grants, and awards), Moderna was also well placed to participate with Pfizer, a 171-year-old Fortune 500 company, in the production of the COVID-19 vaccines. Their only commercial product to date is Spikevax, also known as mRNA-1273 or the Moderna COVID-19 vaccine.

If there had been no pandemic in 2020, or some other commercial breakthrough, Moderna's investors in their RNA project would have been written off someday as sunk costs at an organisational level. Applying traditional accounting practices, the total sum invested would have been spent without achieving the desired outcome.

However, resources put into their RNA research would likely have retained value to the health and pharmaceutical industry at a macro level, retained through the human capital, as they join new initiatives, organisations and teams following a company's voluntary liquidation.

When it comes to non-physical assets, the term 'sunk costs' is a misnomer. Physical assets and knowledge assets do not acknowledge time in the same way.

The transferability of some aspects of the intangible continues beyond the organisation of its origin. Such is the characteristic of these assets. Though sophisticated to quantify, intangible value is retainable and transferable following the dissolution of a project. Hence, the assertion that it can strategically solve unemployment. Not just unemployment as economists defines it, but the ease of movement from one job to another during extenuating circumstances such as a pandemic.

It is not economic unemployment that determines productivity. Productivity is the ability of humans to access how they can make contribution to the economy using the education they have at the time.

\section{The Changed cost of LABOUR When High-VALUE ROLES ARE PERFORMED EXTERNALLY}

Like in the Moderna case, intangible capital is responsible for new, successful entrants into the corporate world. Other contributors to intangible capital include the quality of customer interactions, the ability to remain cyber secure, leadership's effectiveness, the ability to attract new customers and retain existing ones.

The growth of influencer marketing is one of the ways that an employer's labour cost is changing to offset some of the risks employers face when exploring intangibles. Influencer marketing is a marketing strategy that uses the influence of opinion leaders to drive consumer awareness and purchase decisions [2]. This service offers a more affordable alternative to using celebrity endorsers and traditional media channels. Influencer marketing is an industry that was estimated to be worth approximately US\$6.5 billion in 2019 . The industry grows in popularity with brands because it reduces customer acquisition costs while increasing independent content production. According to NeoReach, one trend reporter, for every US\$1 spent on influencer marketing, around US\$5.20 is earned. The average return from traditional marketing is about US\$1.10 (source: Nielson Report). Brands that use this medium often struggle to create the level of engagement themselves. The lack of success is not, however, owing to the skills of employees. This type of consumer trust can only be developed by those autonomous to companies, not employees. Corporations also use network seeding ${ }^{3}$ to identify top influencers whom they engage to share the company's key messages and advertisements independently.

Simultaneously, the growth in platform infrastructure enables this type of crowd-sourced content development. Content exists in two forms: sponsored or unsponsored. Brands are choosing to manage any risks of these engagements since the use of influencers is lucrative and longer-lasting.

Mistakenly, many associate the gig economy or independent working just with exploitation and low-paid insecure work. However, highly skilled professionals also work contractually in this way. In 2017 the UK's professional and business services industry was worth around $£ 186$ billion, representing about $11 \%$ of the economy's gross value add and $13 \%$ of employment. These sectors, including legal services, audit, accountancy, advertising, market research, management consultancy, architectural, engineering and recruitment activities, were once operations within an organisation but considered more cost-effective as an external function.

Even within these already segmented functioning industries there is further segmentation for high-value at reduced cost.

Approximately $20 \%$ of the current professional and business services industry are independent professionals. By working independently, they provide clients with a unique proposition. They offer flexibility, ease, and speed that larger firms cannot adequately provide.

As work evolves, many of the risks held by individuals during the era of the cottage industry, which factories and later corporations once picked up during industrialisation, are being re-positioned with individuals, independent workers (see Fig. 1). Many of them are high-value contributors.

There are unparalleled benefits to having external workers that produce high value to businesses like influencer marketing and independent consulting.

As corporations discover that this external element makes it easier to quantify and communicate the intangible value to investors, the cost of labour is changing.

Due to the scalability of intangibles, high-value work arranged externally reduces costs.

\footnotetext{
${ }^{3}$ Network seeding is an online marketing tactic used to attract segments of customers through social mediums. It involves using selected thought leaders, experts, influencers or even consumers to share corporate messages.
} 


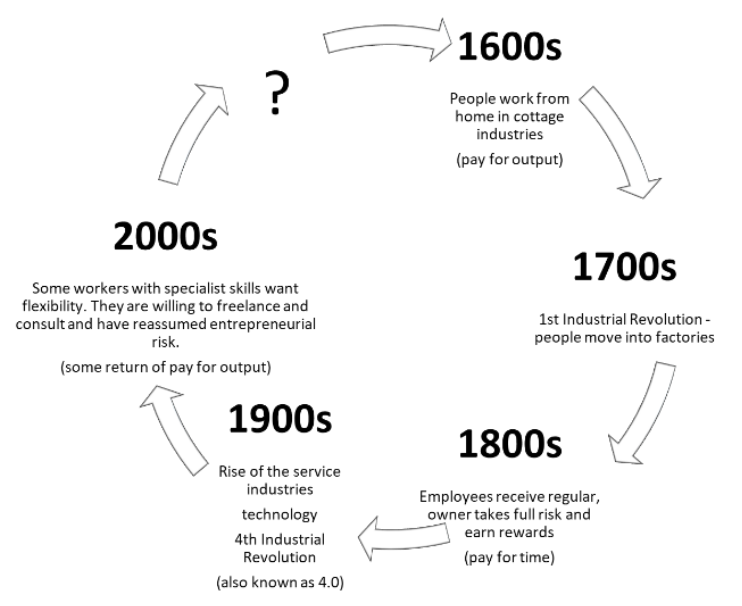

Fig. 1. Risk and work's revolution.

\section{ETHics AND PAy PRACTICES AS Work EVOlVES}

Human capital's contribution outside the organisation links directly to the revenue-generating process (value-driven) and the intangibles these organisations create within. This external structure simplifies the methodology for valuing corresponding intangible.

Nevertheless, the primary method for dividing and remunerating labour has remained rigidly time-based. Timebased pay is however singular. Including risk, as previously described, several other factors contribute to pay.

Renowned American management consultant Alan Weiss raised the ethical issue of time-based pay for the consulting profession in 1992. Weiss had argued that time-based pay was a disincentive to perform quality work at an acceptable speed. He explained that to pay consultants for the value of their potential transformative outcome was the ethical approach. Hourly rates meant that there was an inherent risk for prolonging jobs unnecessarily otherwise. Thus, the ethical basis for charging for value arose within the management consulting industry. Compensation determined by an agreed value-based computation is a common occurrence today within the industry among professionals. As more employers focus on the value employees create and increase the use of external sources of high-value workers, adherence to good corporate governance practices will determine whether the economic divide widens, or poverty thwarted.

In 2016, the World Economic Forum had released its Future of Jobs Report to explain the significance of labour trends by industry and geography. They reported that new classifications of work would emerge. Their research showed that the skills required for both old and new occupations would likely change, transforming where and how people worked. Female and male workers reportedly would be affected differently. The report was explicitly examining changes due to Industry 4.0. It had not anticipated what impact a pandemic would have on transformation timelines.

American Economists Erik Brynjolfsson and Andrew McAfee contributed to the report. They highlighted that the evolution of work could yield greater social inequality as automation substitutes labour across the economy. The other scenario presented involved employing good governing practices. If good governance prevailed, automation could result in more jobs that were safe and rewarding.
These economists also agreed that capital would no longer be the critical factor of production. However, warned, when talent becomes crucial, there could be a rise to job market divisions and increased social tensions.

Signs that some essential governing considerations in the changing nature of work are already symbolic in class actions against fast-growing companies.

In 2020, the US\$52 million class action settlement received by Facebook's content moderators for mental health damage. People performing those jobs suffered trauma following exposure to some of the worst of the internet. Nevertheless, that case uncovered another issue. Content moderation is likely one of those roles' technology will eventually replace labour due to the hazardous and irreparable nature of the work. Are businesses like Facebook using the work that these employees perform to develop algorithms that can help monitor and control posts in the future to safeguard mental health? The logical answer might be yes, which would be sensible. However, it is questionable whether these hourlypaid workers who contribute to the development of new technology are compensated equitably for the value they provide.

Professor Bob Garratt, in his book 'The Twelve Organizational Capabilities: Valuing People at Work' explains 'Many people have either lost, or never had, the concept that organisations are about human life forces, systematic connections and mutual dependency... Organisations are crucially important human institutions. The very terms 'association' and 'company' are powerful reminders of the human need to come together for mutual support, protection, development and recognition.'

While social media has facilitated comprehensive connectivity, companies implementing modern organising models profit from today's new intangible-based economy. However, labour practices and legislation so far are not equipped to deal with these changes. The labour cost has changed as a large proportion of the intangible benefit is more easily derived when the workforce is external to the organisation.

Labour costs are multi-dimensional.

Therefore, the single featured wage regulations that prevail, such as minimum wage per hour, do not sufficiently protect the interests of some modern workers.

How do we arrange labour to create priceless intangible value yet reward accordingly? Open accessibility can be an ethical action that some companies take.

\section{THE OPEN ACCESSIBILITY OF JOBS AND FAKE ACCESSIBILITY}

The abstract sophistication of value contributes to today's trade environment's volatility, uncertainty, complexity, and ambiguity (VUCA).

Though, it is not the first time that the uncertainty and complexities of running businesses posed what looked like insurmountable challenges. In the 1800 s, manufacturing processes required industrial accounting to determine selling prices, assess efficiencies, and analyse data for decisionmaking and planning. Many initially rejected the application of scientific approaches. The solution developed then is known today as Cost Accounting [3]. 
The new economy required the examination of the other side of the revenue equation. It demanded a penetrating look at 'value' to achieve similar goals.

Cost + Value $=$ Revenue

Fig. 2. The Revenue Equation.

Value is not only directly linked to human capital but also intrinsically tied to production and profitability.

When considering value, entry-level jobs created can be high value ${ }^{4}$.

With the right tools and structure, joiners can add unique, psychographic, high value to employers from the very first day of their engagement.

High-value jobs originate on both sides of manufacturing or delivery stages in labour distribution structures [4]. They contribute to research, product or service design, product or service development, innovation, customer service, marketing, branding, product, or service improvements.

This shift in labour investment exists in the manufacturing sector and the development and delivery of services.

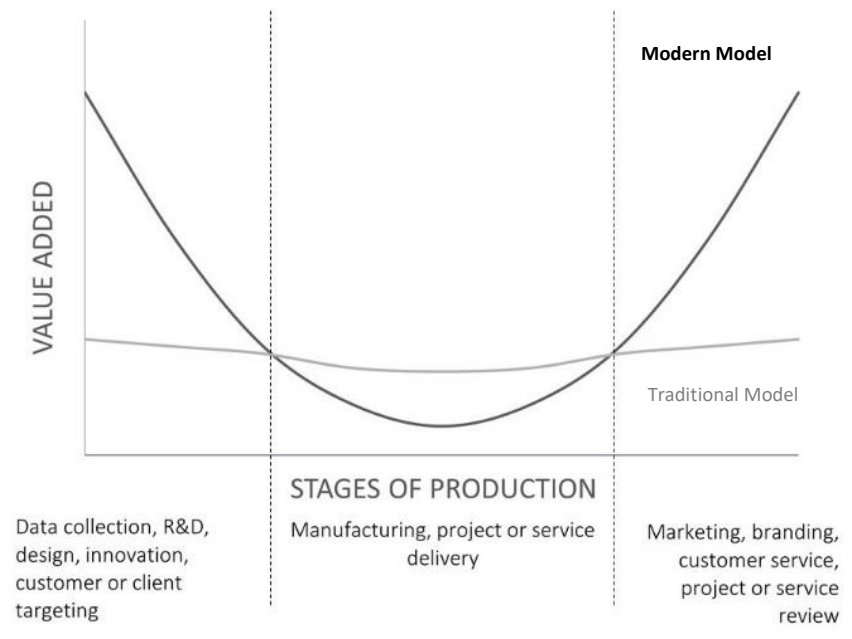

Fig. 3. Stan Shih's Smiling Curve Graph.

During the 1970s, manufacturing businesses had flatter labour distribution structures (the traditional model shown in Fig. 2). However, the value of the services grew in the 1940s, and manufacturers also shifted how they arranged their workforce. Stan Shih had discovered in the 1990s that organising the workforce so more provided value-added services such as research and development, design or customer service, and relatively fewer employees were involved in the manufacturing process yielded higher profitability.

Following this trend, by 2017, fewer employees were hired to produce physical products or deliver services. More were employed to find new markets, discover unique ways of engaging with customer needs, and identify other ways to use the products. The smiling curve ${ }^{5}$ model persists to today and is evident in service-based companies too.

The value-added services that employees provide are

\footnotetext{
${ }^{4}$ High value roles are those that can directly lead to revenue. They appear on both ends of the value chain of Stan Shih's smiling curve graph.

${ }^{5}$ The smiling curve is the name given to the business management theory discovered in the 1990s to show that value-add varies across different stages
}

crucial to growth plans. However, when Stan Shih discovered the smiling curve predates social media and influencer marketing.

Value add is universal and has a great deal to do with individual contributions made, not just the stage in the supply chain. Thus, even non-knowledge workers can deliver added value beyond their assigned department role.

Under the traditional manufacturing structure, there was an assumption that most employees were responsible for maintaining value. Maintained value originates through systems for using machines or processes that the leaders and managers had already designed. However, that outdated structure nullifies that:

(i) anyone can think outside the confines of their job description, department, or sector; and

(ii) the work performed today can be used to develop human-less work for the future (AI).

For example, a factory worker, John, blogs about his industry daily. He reaches out to and interviews specialists in his industry. He enjoys learning about the industry while performing his role in the factory. John pursues all of this outside his usual hours of work. Over the years, he has nurtured a strong online following. John's employer notices his success in attracting a segment of their customers. They leverage his network from time to time to attract new customers. John is also contributing to marketing and branding, not just his role as a factory worker.

This situation is not exclusive to labourers. Professionals with specialisms and technical expertise may also add value outside their area of expertise.

The complexity of how employees can add value has increased.

While the smiling curve had examined value-adding activities from an employer's top-down viewpoint, knowing what we do about intangibles might a more straightforward way be from the bottom-up, where employees are not restricted by a job description but determine themselves how they will add unique value?

When James Dyson became frustrated with his cleaning apparatus in 1978, he took the vacuum apart and realised the bag's problem. Dyson had recently seen a cyclone tower system that used centrifugal force to separate paint particles from the air in a factory building. Looking at the mess on his floor, he wondered whether the principle of that technology could work in a vacuum system to replace the bag. All good ideas begin this way. Dyson was not an employee at a vacuum manufacturer or even someone working in the cleaning industry. In the words of Steven Johnson in his book 'Where Good Ideas Come From', innovation is like a room that magically expands with each newly opened door. Every new room has open doors to explore. Today, Dyson's cyclonic technology creates vacuums and hair care products, fans, heaters, and hand dryers.

To uncover new ideas quickly, companies are also leveraging contractors and communities they have set up to open these new doors to revenue. In Exponential Organisations, Salim Ismail attributes such use of external

of the production process. The graphical depiction of this labour distribution looks like a smile hence the name. 
communities of users, customers, and alumni with the scalability of American companies. Ismail explains that companies with a high exponential quotient score are likely to scale. These virtual communities use the company's products and services and can provide feedback on what works, what flaws there are and identify neglected market segments and other product uses. Communities are like an ever-present focus group. These workers are outside the traditional employment model. They are not employees. Like influencers or independent consultants, they add crucial external value to these businesses.

Many of these roles however remain unpaid.

Author of the 1998 book Corporate Amnesia, Arnold Kransdorff, argued that 'organisational memory' was eroded due to the increasing use of flexible labour markets. There is another argument. Perhaps flexible labour markets harness the growth of the intangible.

Businesses are breaking down tasks to de-risk the process of engaging external participants, resulting in valuable pipelines that extend beyond potential customers. At the same time, high-value jobs created embrace the flexibility that skilled today's labour force wants.

In 1984 Richard Wurman created The Technology, Entertainment, Design Conference (known globally as TED: Ideas Worth Spreading). They curate talks in an eighteenminute format. Before 2001 TED talks would attract about one thousand attendees annually to their base in California. Chris Anderson acquired TED in 2001 and implemented a strategy to realise his vision for expanding the brand into a global operation. That strategy was two-fold. It involved establishing a pipeline of speakers using a franchise model

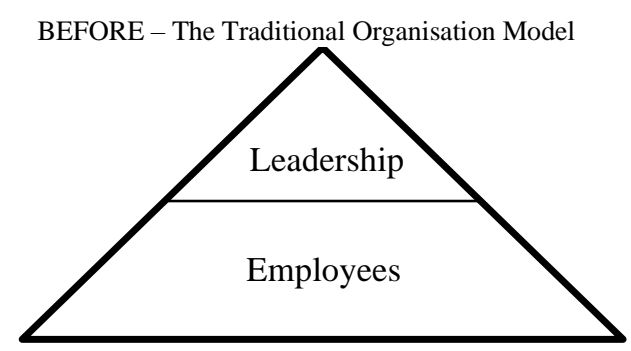

Closed access, selection for work

Departmental mix of work by roles; some roles can include low and high-value jobs

Limited number of jobs available

All jobs advertised based on need

Remuneration based on input time

Requires supervision
Encourages entrepreneurialism and self-

while also making talks accessible to all. Today, well over 10,000 TED volunteers source speakers and curate TEDx and other events globally. The number of employees TED hire in the traditional way is estimated at 500. Although TED is a registered non-profit organisation, before TED, Anderson, a British-American, had successfully grown Business 2.0, a monthly magazine that had chronicled the rise of the new economy. Time Inc acquired the publication.

The book Exponential Organizations explains that a similar model exists across several other corporations, including GitHub, The Coca Cola Company, The Guardian, Amazon, Zappos, ING Direct Canada, and Google Ventures. The 'staff on demand' trend will continue as this new breed of organisations are scaling and generating value at a pace. While the market cap to a billion used to take the typical Fortune 500 Company 20 years, today's exponential organisation scales in much less time; Google took eight years, Facebook took six years, and Tesla took four years.

This modern structure is already in practice by some companies, with little understanding of the economic and social consequences, thereby creating fake accessibility. Fake accessibility exists when open sources fail to serve society because there is a flaw in the remuneration distribution for value.

As the future is shaped, structured research into the transformation to create open access employers will reveal legislative frameworks needed to adequately support workers. A comparison of what this transformation could like look is available in Fig. 4.

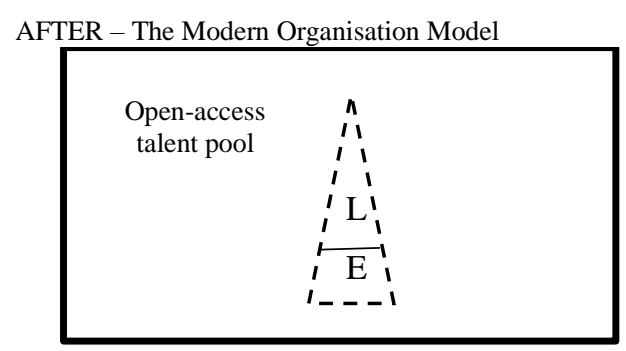

Open access, registration for work

Strategic mix of internal and external workers based on risk and value of the work

Unlimited number of jobs for registered workers, managed by an Agent (this process is IR35 compliant in the UK)

Internal employment advertised based on strategic expansion

Mixed remuneration; consideration of result, value, time and risk

Encourages entrepreneurialism and self-management

Fig. 4. Transformation to facilitate open access employment.

\section{CONCLUSION}

Despite the growth of gig-working platforms, influencer marketing and independent consultants, there is a dearth of strategic academic insight into what open job accessibility can achieve. In addition, there is likely a wide range of ethical issues to ponder. What actions might address fake accessibility? What determines whether high value roles performed internally are being exploitative? What is the societal impact if modern organisational design continues on

\section{its current trajectory?}

If there is already data or studies that contradicts or supports the claim that intangibles can solve unemployment, understanding the circumstances under which the use of intangibles can be a significant part of post-COVID-19 economic recovery efforts worldwide.

As new industries develop and old one's fade, businesses have had to revise their mix of investments throughout history. So, imagine how differently tackling other vital issues like climate change or poverty would look if the fear of mass job loss were no longer a threat. 
Ocean Tomo's report that these non-physical assets now represent about $90 \%$ of market capitalisation in companies on the Standard \& Poor's index. Up from around 80\% six short years ago, the trend shows that enough is already known about intangibles to shape how organisations organise their people for a competitive edge.

There is no agreement for an integrated reporting framework that can aid consistency when monitoring environment or societal impact. So many leaders are perhaps remiss of the long-term opportunity that exploring intangibles seriously during a period of economic recovery can have.

Additionally, fake accessibility might likely put any recovery plans in jeopardy if it widens the wealth gap further. Regulated wages adopted internationally are ineffective for value scenarios. In the UK's service sector contribution to GDP had almost doubled over the 65 years between 1948 and 2013, as manufacturing production had fallen. Despite this change, legislation has not accounted sufficiently for servicebased value contribution. Piece work and unmeasured work are linked to time work without considering the benefit to the employer (value), leaving a large population of workers at risk of being poorly rewarded for their contributions. Policymakers can begin consultation studies and invest in transformation research that prepares to update labour legislation.

This field of study requires deep work. Further research can determine what proportion of businesses with modernised open-access employment would create an environment that encourages diversity and inclusion. Experimenting can also assess which business size would create the most significant impact so limited resources could be invested accordingly. The trouble is who chooses which businesses are supported to grow in this way and perhaps create anticompetitive markets.

The challenges presented by the pandemic require innovation, audacious solutions likely to stand the test of time. A bold and pioneering plan to improve workplace accessibility, using what is known about intangibles, could be one way to address economic instability and match the open accessibility of education.

\section{ACKNOWLEDGMENT}

The Author wishes to thank: Prof. Bob Garratt, Professor Extraordinaire at the University of Stellenbosch and Visiting Professor at the Bayes Business School (formerly Cass); Calvert Markham, Visiting Professor of Management Consulting at the Bayes Business School (formerly Cass); Patrizia de Corato, Assistant Professor at the University of Lebanon.

\section{REFERENCES}

[1] Haskel, J., Westlake, S., (2017), Capitalism without Capital: The Rise of the Intangible Economy,

[2] Lou \& Yuan, 2019

[3] Fleischman, Richard K., and Thomas N. Tyson. (1993), "Cost Accounting during the Industrial Revolution: The Present State of Historical Knowledge." The Economic History Review, vol. 46, no. 3 , pp. 503-517., www.jstor.org/stable/2598365. Accessed 9 Aug. 2021.

[4] https://www.researchgate.net/figure/The-Smile-curve-of-GVCsSource-Shih-1992_fig1_325274330.
[5] Bryan, L. L., Joyce, C. I., (2007), Mobilising Minds: Creating Wealth from Talent in the 21-st Century Organisation.

[6] Chen, L. \& Shupei, Y., (2019) Influencer Marketing: How Message Value and Credibility Affect Consumer Trust of Branded Content on Social Media, Journal of Interactive Advertising, 19:1, 58-73, DOI: 10.1080/15252019.2018.1533501.

[7] Garratt, B., (2000), The Twelve Organizational Capabilities: Valuing People at Work

[8] Gershuny, J., Robinson, J.P., (1998) Historical changes in the household division of labor. Demography 25, 537-552. https://doi.org/10.2307/2061320

[9] Goldin, C., (2006), The Quiet Revolution That Transformed Women's Employment, Education, and Family, Ameri.can Economic Review, Vol. 96 No. 2 Richard T. Ely Lecture.

[10] Ismail, S., Malone, M. S. and van Geest, Y., (2014), Exponential Organisations: Why New Organisations are Ten Times Better, Faster, and Cheaper Than Yours (and what to Do about It).

[11] Kelly, K. (2016), The Inevitable: Understanding the 12 Technological Forces that will Shape our Future.

[12] Morgan, J., (2017) The Employee Experience Advantage: How to Win the War for Talent by Giving Employees the Workspaces They Want, the Tools They Need, and a Culture They Can Celebrate.

[13] Müller-Stewens, G., (2020), The New Strategist: Shape Your Organisation and Stay Ahead of the Game.

[14] Weiss, A., (1992), Million Dollar Consulting: The Professionals Guide to Growing a Practice.

[15] https://core.ac.uk/download/pdf/7051857.pdf.

[16] https://economictimes.indiatimes.com/news/economy/policy/thecurious-case-of-investment-ineducation/articleshow/80306498.cms?from $=$ mdr.

[17] https://hireinfluence.com/blog/highest-paid-influencers/

[18] https://influencermarketinghub.com/influencer-marketing-2019benchmark-report/.

[19] https://scholar.harvard.edu/files/goldin/files/the_quiet_revolution_that _transformed_womens_employment_education_and_family.pdf.

[20] https://www.irishtimes.com/business/technology/facebook-ussettlement-for-moderators-does-not-apply-to-irish-cases-1.4252611.

[21] https://www.mcgill.ca/maut/news-current-affairs/moocs/history.

[22] https://www.nielsen.com/us/en/insights/article/2009/maximize-thereturn-on-your-advertising-spend/.

[23] https://www.odgersconnect.com/fileadmin/uploads/ob/Documents/Th e_Rise_of_Independent_Professional_Work__Changing_Demand_fr om_European_Employers.pdf.

[24] https://www.parliament.uk/globalassets/documents/commonscommittees/Exiting-the-European-Union/17-19/Sectoral-Analyses/28Professional-and-Business-Services-Report-.pdf.

[25] https://www.researchgate.net/profile/Colin-Campbell16/publication/340255557_More_than_meets_the_eye_The_function al_components_underlying_influencer_marketing/links/5eb9fabc9285 1cd50dab4ad7/More-than-meets-the-eye-The-functional-componentsunderlying-influencer-marketing.pdf

[26] https://www.researchgate.net/publication/325274330_Trade_in_Intan gibles_and_A_Global_Value_Chainbased_Framework_of_International_Trade\#pf9.

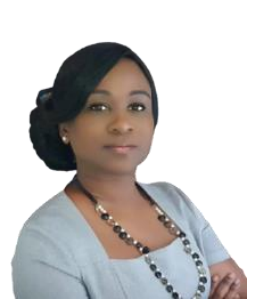

Over her 20+ years' career Rhonda A. Best has worked primarily within service businesses. In 2007, while a Director at one of Europe's top property investment firms, she discovered that the traditional range of taught accounting solutions could not provide the deep analytics her Board needed to provide oversight. What was required were new assessment tools. Analytics that would link the intangible value employees delivered, with overall performance.

With that insight executives could have a sensible approach to prioritize and distribute limited financial resources. This led to Rhonda's investigation of solutions to address modern financial weaknesses and creation of the algorithm that facilitates a method she calls Value Analytics ${ }^{\mathrm{TM}}$.

Rhonda is the Founding Director at British Management Consulting firm, Alexander Bain and Associates Limited. In 2004 she was awarded a Bachelor of Science in Applied Accounting from Oxford Brookes University and qualified as a Chartered Accountant with the Association of Chartered Certified Accountants (ACCA) the same year. In 2009 she was admitted as an ACCA Fellow and was awarded a Master of Business Administration degree from Oxford Brookes University. She is a member of the City of London's Management Consulting livery, a Committee Member at the Centre for Management Consulting Excellence. And is the former Hon Treasurer and Committee Member at the Livery Companies Skills Council. Over her career, Rhonda has also served on the Council of the ACCA 
European Journal of Business and Management Research www.ejbmr.org

ACCA's Corporate Network Sector Panel, ACCA's Small \& Medium-sized Enterprises (SME) forum, the UK's All Party Parliamentary Group for the International Trade of Professional Services and on boards in small and medium-sized businesses internationally. 